\title{
Cikkismertetés: A szénhidrátok minősége és az emberi egészség: a témában megjelent áttekintő tanulmányok és metaanalízisek
}

\author{
Article review: Carbohydrate quality and human health: a series of \\ systematic reviews and meta-analyses
}

Ismertető: $\quad$ Varga Anita $\square$

Országos Gyógyszerészeti és Élelmezés-egészségügyi Intézet

Ismertetett cikk: Andrew Reynolds, Jim Mann, John Cummings, Nicola Winter, Evelyn Mete, Lisa Te Morenga: Carbohydrate quality and human health: a series of systematic reviews and meta-analyses, The Lancet; 2019, 393(10170):434-445. doi:10.1016/S0140-

6736(18)31809-9

Beküldve: $\quad$ 2019. 02. 01.

doi: $\quad$ 10.24365/ef.v60i1.415

Kulcsszavak: krónikus nem fertőző megbetegedések; szénhidrátok; élelmi rostok; teljes kiőrlésű gabonafélék; táplálkozási ajánlások

Keywords: non-communicable diseases; carbohydrates; dietary fibre; whole grains; dietary guidelines

A tanulmány az Egészségügyi Világszervezet (WHO) támogatásával valósult meg a szénhidrátokra vonatkozó jelenlegi táplálkozási ajánlások felülvizsgálata céljából. A témában megjelent eddigi felmérések általában vagy csak az egyszerú cukrok egészségre gyakorolt hatását vizsgálták (például, a fogszuvasodás, a túlsúly és az elhízás vonatkozásában), vagy csak limitált klinikai eredményeket adtak. A táplálkozási ajánlások ennek megfelelően alapvetően az étkezési cukrok bevitelének csökkentését célozzák meg, és kisebb hangsúlyt fordítanak az egyéb szénhidrát komponensek, mint például a keményítők vagy az élelmi rostok szerepére.

A szerzők az eddig megjelent tanulmányok elemzésével világítanak rá arra, hogy milyen összefüggés figyelhető meg az elfogyasztott szénhidrátok minősége és a krónikus nem fertőző megbetegedések előfordulása, kockázati tényezői és a halálozás között. A 2018. február 28-ig összegyűjtött publikációk elemzésével a következő kimagasló adatmenynyiséghez jutottak: 185 prospektív vizsgálat által közel 135 millió személyév, az 58 klinikai vizsgálat által 4635 felnőtt vizsgálati személy.

A szénhidrátok minőségének meghatározása során figyelembe vették például az élelmi rosttartalmat, a teljes kiőrlésű gabonafélék fogyasztását (mert a legkiemelkedőbb élelmirost-források), valamint a glikémiás index és a glikémiás terhelés mértékét. Az elemzések alapján megállapítható, hogy a legmagasabb élelmirost-fogyasztók körében 15-30\%-os csökkenés figyelhető meg az össz- és a szív-érrendszeri megbetegedésekből eredő halálozás, a koszorúér betegségek, az agyvérzés, a 2-es típusú cukorbetegség és a vastagbéldaganat előfordulási gyakoriságában, szemben a legalacsonyabb élelmirost-fogyasztókkal. Ezeket az eredményeket 
támasztották alá a klinikai vizsgálatok eredményei is: a magasabb rostfogyasztóknál alacsonyabb testtömeg, alacsonyabb szisztolés vérnyomás és összkoleszterin érték volt megfigyelhető. Az összes tanulmányt figyelembe véve, a dózis-válasz görbe elemzések alapján megállapítható, hogy a rostbevitel növelésével arányosan nagyobb lesz a védelem a szív-érrendszeri megbetegedésekkel, a 2-es típusú cukorbetegséggel, a vastagbél-, nyelőcső- és az emlőrákkal szemben egyaránt. Az eredmények hasonlóak voltak a teljes kiőrlésű gabonafélék fogyasztásának megfigyelése során is. Azonban a glikémiás index vagy a glikémiás terhelés vizsgálatakor csak kismértékű kockázatcsökkenés, vagy a kockázatcsökkenés hiánya volt megfigyelhető.

\section{TANULSÁGOK A HAZAI SZAKEMBEREK SZÁMÁRA}

Az elemzés meggyőző bizonyítékot szolgáltat arra vonatkozóan, hogy a rostdús táplálkozás jelentős pozitív hatással van az egészségi állapotra, ezért a népegészségügy területén is kiemelkedő figyelmet kell fordítani erre. Az eredmények tükrében a táplálkozási ajánlásokban hangsúlyozni szükséges, hogy az élelmirostbevitel érje el a legalább 25-29 gramm/nap mennyiséget, emellett a teljes kiőrlésű gabonafélék nagyobb arányú fogyasztása, és a finomított szénhidrátok bevitelének csökkentése javasolt. 